\title{
Electoral Malpractice, Integrity of the Election Management Bodies: A Case of 2015 Simultaneous Elections in East Java
}

\author{
Kris Nugroho \\ Department of Politics \\ Airlangga University, Faculty of Social and Political Sciences, \\ bkung_65@yahoo.com
}

\begin{abstract}
This article examines that the integrity issues of the election management bodies (EMBs) become an obstacle for the realization of the electoral integrity. The norms or electoral laws are not strong enough to produce EMBs that have high integrity in the framework of implementing the tasks and authority. In reality, some EMB members involve in the violation cases of the electoral norms. These problems have been found in the simultaneous local elections in East Java where electoral violations committed by the EMBs can be described into three patterns of violations. First, they become partisans for or take sides to particular candidate pairs for regional head. Second, they create policies that decrease political equality for some candidates. Third, they act unprofessionally, be careless in doing their jobs and give rise to legal uncertainty. The cases of electoral violations committed by EMBs illustrate the problem that the integrity of EMBs is still low and needed to improve.
\end{abstract}

Keyword: Electoral integrity; Political party

\section{INTRODUCTION}

Article 1(5) of Law No. 15 Year of 2011 regarding General Elections mentions that General Election Commission (KPU) and Election Supervisory Body (Bawaslu)are unity of functions of EMBs in Indonesia. The general elections are to vote the House of Representatives (DPR, DPD and DPRD), the president and vice president, governor, vice governor, regent and deputy regent, mayor and deputy mayor. Article 2 of Law No. 15 Year of 2011 also mentions that the EMBs, in carrying out their duties, should be independent, honest, just, have certainty of law, orderliness, public interests, transparency, proportionality, professionalism, accountability, efficiency and effectiveness. ${ }^{1}$

The substance of those principles mainly requires the EMBs to have high integrity in holding the processes of general elections. The general elections held by the EMBs that have

\footnotetext{
${ }^{1}$ Article 1 and 2 of the Law Number 15 Year of 2011 about the EMBs
}

high integrity would, in turn, produce democratic elections with high-grade and integrity.

Article 2 of Law No. 15 Year of 2011also states different authorities between KPU and Bawaslu. KPU holds the authority to conduct the processes of general elections such as updating the voters data, handling the voters' registration, arranging the campaign schedules, holding the elections, calculating the votes, and determining the result of the elections based on the prevailing regulations of general elections. On the other hand, Bawaslu holds the authority to perform supervisory functions in the electoral stages and to give recommendations to KPU if there are administrative and electoral violations.

The working basis of both institutions is the law that regulates general elections and guides the electoral processes to generate democratic elections regarding to the electoral laws and norms. To achieve the goal of generating democratic elections, thus, the EMBs are not allowed to commit electoral fraud that could violate the principles of integrity in 
conducting general elections or to give priority to personal interests before public interests. (Wall, 2006 p. 24).

Based on the concept of the above EMBs integrity, this article would examine the integrity issue of the EMBs in the 2015 simultaneous election that was held in 19 cities and regencies in East Java on December 9, 2015. The author tries to reveal that the EMBs partiality to certain candidates does not only violate the principle of integrity but also can potentially damage the processes and the results of general elections.

The purpose of this article is to create an institutional strengthening design of EMBs that has high integrity by learning from and evaluating the violation cases of the electoral laws in the 2015 simultaneous local elections in East Java. Some violation cases of the electoral norms and ethics involving the EMBs are taken as a starting point to build the analysis and the institutional strengtheningdesign of EMBs that has integrity.

\section{The EMBs Integrity}

The definition of EMBs integrity refers to the commitment of the EMBs to reinforce and consistently uphold the existing laws and ethics in conducting general electionsin accordance with universal norms of democratic elections. There are two important aspects regarding this concept. First, the duty and authority of the EMBs are based on the electoral law and they have to make technical and operational electoral policies in accordance with the electoral laws. Second, the EMBs are bound by the norms and ethics as the basis to produce democratic elections with high integrity. The EMBs are not allowed to work with any parties and/or electoral candidates to commit electoral fraud.

The electoral integrity refers to a set of value system that the legislation aims to produce democratic, just and trustworthy elections with legal certainty. Electoral integrity is the ethical concept and also the legal validity of the electoral processes that are held according to universal values of democratic elections; professional, impartial, and transparent in the whole processes of the implementation (Aceproject, 1998 p.9).

In Indonesia, the EMBs (KPU and Bawaslu) are given the authority by the constitution as the institutions in charge of organizing and monitoring the election. It has already been their responsibility to uphold the electoral norms to ensure that all stages of the election run accordingly and appropriate with the choice of the people. In this regard, the EMBs and the participants of the election should not do coercion, ballot manipulation, money politics, electoral abuses that can cause detriment to the voters' right to be lost or removed and manipulation by adding or reducing the recapitulation. Moreover, they should not do conspiracy that leads to crimes involving the EMBs and the participants of the election.

The responsibility of the EMBs is to transform the votes into the representative seats, thus, the EMB members should be the people who meet the qualifications including the aspect of honesty, ability to act justly and have a strong commitment to produce credible elections. To support these achievements, the EMBs should work based on several principles which are independent, impartiality, integrity, transparency, efficiency, professionalism and service-priority (Aceproject, 2006).

Referring to the standards of the International Institute for Democracy and Electoral Assistance (Wall, 2006: 22), the EMBs should be guided by the following principles: independency, impartiality, integrity, transparency, efficiency, professionalism, service priority and give priority to the work order that is accountable from the legal aspects.

The same principles also become a benchmark in holding the elections in Indonesia as stated in Article 2 of Law No. 15 Year of 2011 about the EMBs that are independent, honest, just, have certainty of law, orderliness, public interests, transparency, proportionality, professionalism, accountability, efficiency and effectivity. 
The above principles of the election are normative, moral and ethical demands functioning as a rule of conduct that bind the EMBs in realizing their duties. If the EMBs could implement the values of democratic elections consistently in the practices of general elections, it then will generate general elections with high integrity and could minimize the possibility of electoral misconduct to happen (Birch, 2007).

The actors of electoral misconduct potentially come from the parties which have authority or interests in elections either the EMBs or the electoral participants (the parties and/or the candidates). If electoral violations are committed by the EMBs, it further leads to a form of abuse of the authority that has been entrusted by the law to the EMBs that should be carried out. These violations include doing administrative manipulations during the voters' registration, making electoral policies or rules that give detrimental or beneficial to certain parties, candidates or voters, taking sides to certain parties, doing personal intervention on the process and/or the result of the election and being involved in the transactions contain of materials or money for personal gain. Meanwhile, the form of electoral violations committed by the electoral participants generally aim to influence the result of the votes by blocking the voters to choose, using physical or non-physical violence to the voters or candidates, or performing vote-buying or bribery involving the EMB members.

Referring to the Law No. 8 Year of 2012 about General Elections, if it is associated with the actors of the electoral violations, the electoral violations can be classified into specific and general violations. Practices of specific violations include criminal and administrative violations. For example, the members of EMBs receive money from electoral candidate pairs or manipulate the result of the votes causing an increase or a decrease of the votes.

The practices of general violations are including the acts of violating and breaking the electoral laws such as the threat of violence, the destruction of electoral facilities, intimidation, money politics, intervention and blocking other parties to vote.Referring to the Law No. 8 Year of 2012, these actions can be categorized as electoral violations.

The important concept to be emphasized in this article is the integrity of the EMBs that refers to a set of norms and values of electoral democratic serve as the rule of conduct for EMBs in carrying out the stages of the election in conducting the electoral processes and results that are legitimate, trustworthy, transparent and reflecting electoral justice. The norms of democratic elections refer to the implementation of the electoral principles that are honest, just, direct, free and confidential. More substantively, the integrity of the EMBs is measured from their commitment to act according to the norms of democratic elections: independence, impartiality, honesty, transparency, and professionalism, giving priority and providing well services to all parties and upholding the works and are accountable for the legal aspect.

\section{The Concept of EMBs ${ }^{2}$}

The concept of EMBs refers to the election management bodies that have responsibility and authority to hold elections to choose representatives of the people who are credible based on the principles of independence, impartiality, and integrity, professionalism, transparency, efficiency and voters' serviceoriented (Wall, 2006). The concept of EMBs has different names in some countries, but its main function is to hold elections (Pintor, 2000). For example, the EMB in Australia is managed by the Australian Electoral Commission, in the United States is managed by the Federal Electoral Commission, in Mexico is managed by the Federal Electoral Institute (Instituto Federal Electoral), in Paraguay is managed by the Supreme Tribunal of Electoral Justice, in Honduras is held by the National Electoral Tribunal, in Russia is conducted by the Central

\footnotetext{
${ }^{2}$ The term Election Management Body refers to Chapter IV, Article 15 of the Law Number 12 Year of 2003 about the Election of the House of Representatives(DPR, DPD and DPRD). The EMBs in accordance with the Article is KPU (Article 1 dan 2).
} 
Election Commission, and in South Africa is managed by the Electoral Commission.

In the context of the needs of each country, EMBs can be national and local. National EMBs are related to the duties and authority to organize legislative elections / national parliament. Local EMBs are responsible for holding the election to choose members of local parliament or regional head in Province / District / City in Indonesia or the state level as in India. However, the legal frameworks that become the basis for the national and local EMBs still refer to the applicable normative principles in each country.

In the context of Indonesia, the EMBs refer to the General Election Commission (KPU). ${ }^{3}$ While Bawaslu and Panwaslih, they are indirectly involved technically, administratively and operationally in organizing the elections. Bawaslu and Panwaslih have the authority to perform supervisory functions in the election stages. ${ }^{4}$ Besides KPU and Bawaslu, Law No. 15 year of 2011 about General Elections also includes DKPP with the duties and authority to perform the judicial functions related to violations of the ethical code committed by EMBs.

\section{CASES}

The integrity of the EMBs is still considered as a major constraint to produce democratic and fair elections. It can be seen in the 2014 legislative elections and the 2015 simultaneous elections in East Java. The integrity issues turned into the topic of the day as some members of the local EMBs received gratuities, and took side to certain candidate pairs. For example, The Honorary Council of Election Management Body (DKPP) dismissed 13 members of the local EMBs in Pasuruan regency

\footnotetext{
${ }^{3}$ The explanation about the legality of KPU can be seen in Article 15 of Law No. 12 Year of 2003 and Article 1(6) of Law No. 15 Year of 2011 that explicitly mention KPU as the EMB

${ }^{4}$ The Election Supervisory Bodies are Bawaslu and its components that can be seen in the Article 69 of Law No. 15 Year of 2011
}

for receiving gratuities from certain candidates, in exchange for votes (2014); 1 member of Panwas Lamongan for being sympathizer of a political party (2015); and 2 members of KPU Situbondo for siding with one of the regent candidates (2015). The data of DKPP show 17 cases of alleged electoral violations committed by the EMBs throughout the year of 2015 (DKPP, 2016: 69).

The 2015 simultaneous elections in East Java were held in 19 Regencies and Cities, namely in Regencies of Lamongan, Ponorogo, Situbondo, Trenggalek, Sumenep, Malang, Blitar, Tuban, Ngawi, Jember, Kediri, Gresik, Mojokerto, Banyuwangi, Sidoarjo, Pacitan and Blitar City, Surabaya and Pasuruan Cities. The number of constant voters on the simultaneous election is 18.771 .960 spread over 41.002 polling stations. ${ }^{5}$ This number of voters is the highest among the simultaneous elections in Indonesia. These voters have voting rights to choose candidates for regional heads coming from the incumbents or the non-incumbents.

Besides the single candidate pattern as in Blitar Regency, electoral competitions for the position of the regional head in East Java can be classified into patterns of non-incumbent vs. incumbent (Surabaya); incumbent vs. vice incumbent (Sidoarjo); incumbent vs. independent candidates (Gresik); incumbent vs. newcomers (Trenggalek). Consequences of these patterns of competition bring implications on the tightness of the competition that encourages the candidates and their campaign teams to use the existing political resources to boost their political electability. Even the incumbent position that is considered too strong, as Tri Risma and Wisnu Buana, becomes an excuse for the political parties to not register their candidate couples. This phenomenon is used by several political parties in Surabaya to establish a line called the Koalisi Majapahit (Coalition of Majapahit) in order to block the nomination of Tri Risma and Wisnu Buana. As the result, the stages of the simultaneous election to choose the mayor / deputy mayor of Surabaya was about to

\footnotetext{
${ }^{5}$ visit https//data.Kpu.go.id/dpt2015.php
} 
fail because there were no parties registering their candidate pairs.

Although the local election in Surabaya did not lead to a serious case of electoral violations, but the reluctance of the parties to register their candidates with the reason of inability to compete with a strong incumbent candidate becomes a new 'boycotting' mode of simultaneous elections. This case became a mode in the local election in Blitar Regency where PDI-P carried Drs. H. Rijanto, M.M. as the Regent Candidate and Marhaenis UW as the Vice Regent Candidate without any opponents of candidate pairs from other parties or coalition of parties. The same mode also occurred in Pacitan Regency where the candidate from PD was considered to have high electability so the other parties were reluctant to register their candidate pairs.

The main challenge for the EMBs in East Java general elections is theneutrality aspect of the EMBs. This pattern of violation narrows to the non-neutrality of the EMBs in treating the electoral candidate pairs. This case was experienced by Mojokerto Regency which was reported by the attorney of the candidate pair of former vice-regent, Choirun Nisa - Arifudinsyah, to DKPP. In this case, the KPU of Mojokerto Regency was assessed taking side to the incumbent candidate pair of Mojokerto regent, Mustofa Kamal Pasa - Pungkasiadi. The other regent and deputy regent candidate pair, that depart from personal back up, is Misnan Gatot Rahma Shofiana.

The complaints to KPU of Mojokerto Regency become interesting because the classical problem appeared from the conflicts between the incumbent regent and the incumbent vice regent, who each registered as the candidate from different parties. Mustofa Kamal Pasa-Pungkasiadi ran for the election with the support of PDI-P, Gerindra, NasDem, Golkar, PD, PAN and PKS. In contrast, Choirun Nisa - Arifudinsyah were supported by PKB, PPP, PBB and Hanura. In this case, the problem is that PPP has two managements of DPP; Djan Faridz vs. Romahurmuzy, that in this nomination became one of the political supports for Choirun Nisa - Arifudinsyah.

The point of the complaint from Choirun Nisa - Arifudinsyah attorney to KPUD is its nonneutrality in making decisions regarding to the Decree of DPP-PPP for Djan Faridz which was used in the candidacy registration. Mustofa Kamal Pasa - Pungkasiadi presumed that the DPP recommendation Decree of Djan Faridz was illegal and the DPP of Djan Faridz was considered issuing the Decree. The presumption of the illegal Decree became the legal pretext for the attorney of Mustofa Kamal Pasa Pungkasiadi to sue the opponent party to the MA (Supreme Court). In this regards, the Supreme Court issued a decision that cancelled the determination of the incumbent candidate pair of Mojokerto former vice regent, Choirun Nisa Arifudinsyah.

Based on the decision of the Supreme Court, the legal counsel of Chorun Nisa Arifudinsyah complained to DKPP with the concern that the KPU was assessed taking sides to one of the candidate pairs. Although this presumption of KPUD's partiality was not proven, yet, this case reveals another classical problem that is the chaotic management of the parties in Indonesia due to the conflict of dualism in the management.

The neutrality issue of the EMBs matters when the election moves into the regime of regional head election where the formal and informal political powers intervene and suppress the KPUD commissioners' independence. In context to establish electoral democracy that can change the authentic voters that are in accordance with the people's choice, the EMBs neutrality has to be absolute. Therefore, the EMBs neutrality is an important aspect to realize the electoral integrity. With strong EMBs neutrality, both formal and informal political powers that potentially threaten the EMBs independence can be minimized.

The existence of the electoral integrity represents a value commitment of the EMB 
members to act in accordance with the norms of democratic elections. The implementation of the electoral integrity can also be measured from to what extent the EMBs make operational electoral policies that bring legal certainty, equality for all people / participants of the election, impartiality, professionalism and independence.

The next pattern is the presumption of electoral violations committed by the EMBs that occur before and after the Election Day. The violations committed by the EMBs are generally associated with violations of electoral administrations. For example, voters are not registered or ad hoc officers who enlist the voters take sides and do not act accordingly. This case occurred in Situbondo Regency, where KPUD commissioners were reported to DKPP by groups of community for ignoring the recommendation of Panwaslu (Election Supervisory Committee) that KPU should repeat the data collection for NKK and NIK that have problems.

Referring to the cases above, the pattern of electoral violations committed by the EMBs before the voting day, related to the issues of the electoral administration, tends to be a pretext for the electoral competitors to denounce the EMBs to Panwaslu or DKPP. The point of the denouncement is that the EMBs are assessed partial and taking sides to certain candidates. This case was found in Banyuwangi where the KPU was assessed by one of the candidate supporters acting partial for giving different treatment in terms of the registration legality of the candidate pairs. In this case, the incumbent regent candidate pair, Abdullah Azwar Anas Joseph Widiatmoko that are supported by Democrat Party, is required to complete the nomination file with the legal stamp Decree of Democrat Party. On the other hand, the other candidate pair, Sumantri Sudomo - Sigit Wahyu Widodo that are supported by Golkar Party Munas Ancol, is not required. Although this case did not lead to DKPP's Court, yet, the policy made by KPU of Banyuwangi Regency was noted by Panwaslu to give warning to KPU of Banyuwangi Regency. As the consequences, KPU of Banyuwangi Regency was assessed to be not neutral and not upholding the political equality for all pairs of candidates.

The next pattern of electoral violations committed by the EMBs is the impartiality issue. This is influenced by the context of the struggle in simultaneous election causing the division in local political leaderships into political chase. It further illustrates trade-off situations between formal and informal politics in the context of political struggle for position 'the number 1 person' in each area. Eventually, the implication of the tension between formal vs. informal politics brings the local EMBs into the circle of local interest conflicts.

The presumption of the EMBs involvement for acting partial or taking sides to certain party could bring the EMBs in a critical position to be questioned or denounced judicially. For example, the dismissal of two KPU commissioners of Situbondo Regency by DKPP for taking side to one party, acting beyond their authority and violating the ethical code. They were guilty for abusing their authority siding with one certain candidate. Partiality issues also became a consideration for DKPP to dismiss Muttaqim from the member of Panwaslu Lamongan. He was dismissed for concurrent positions as party leaders. The action of Panwaslu Lamongan member works against the essence of EMBs that must be independent in accordance with the Article 2 of Law No. 15 year of 2011 about EMBs.

\section{CONCLUSION}

In the perspective of local politics, the integrity of EMBs is vulnerable to be influenced by the dynamic trends of political interests of regional head candidates. The interest dynamics can bring the EMBs into the circle of pragmatic interests, whether the violations are in the forms of electoral crimes, electoral administration abuses, and breaking of the EMBs ethical code.

Based on the cases discussed, there are four patterns of the electoral violations committed by the EMBs, which are: the commissioners are partial or take sides to 
certain candidate pair in the stages of local simultaneous election; commissioners issue policies at the stage of the nomination emerging political inequality between pairs of candidates; commissioners issue policies that lead to the violations of electoral administrations; commissioners are not transparent and they lie to the public related to their position as boards of political parties.

The above four patterns of violations committed by the EMB members lead to a degradation of the EMBs integrity. If the degradation of the EMBs integrity has become institutionalized patterns and happened continuously, it will bring a low electoral integrity. Therefore, choosing the EMB members who have high commitments to uphold the norms of democratic elections and implement it professionally into the electoral policies can be the first step to produce the electoral integrity. In the future, to produce institutional strengthening in order to produce a strong electoral integrity, the EMBs should be held by commissioners who are highly competent, have electoral experiences and good understanding, and have a strong commitment to implement values and standards of democratic elections.

\section{REFERENCES}

Ace Project. Electoral Management Body, https://aceproject.org/aceen/topics/em/emc/emc02q/default.

Birch, Sarah. (2007). Comparative Political Studies Vol. 40 No 12 Dec.

DKPP. (2016). DKPP Outlook 2016 Refleksi dan Proyeksi. Jakarta

DKPP. (2015). DKPP Di Tahun Politik (Sebuah Catatan Reportase). Jakarta

Norris, Pippa. (2013). The New Research Agenda Studying Electoral Integrity. Electoral Studies. (2013)/doi:10.1016/j.electstud.2013.07.0 15.
Pintor, Rafael-Lopez. (2000). Electoral Management Bodies as Institutions of Governance. UNDP-IFES.

The ACE Encyclopaedia : Electoral Integrity.1998 (www.aceproject.org)

The International Idea Handbook (2006). Electoral Management Design. AceProject, 2006

UU Nomor 12 Tahun 2003 Tentang Pemilu Anggota DPR, DPD dan DPRD

UU Nomor 15 Tahun 2011 Tentang Penyelengara Pemilu

Wall, Alan et al. (2006). Electoral Management Design. Stockholm. The International IDEA Handbook. Publications Office International IDEA. 